Papers and Proceedings of the Royal Society of Tasmania, Volume 117, 1983.

(ms. received 8.9 .1982$)$

\title{
A BRIEF HISTORY OF LICHENOLOGY IN TASMANIA
}

by G. Kantvilas

Department of Botany, University of Tasmania

ABSTRACT

KANTVILAS, G., 1983 (31 viii): A brief history of lichenology in Tasmania. Pap. Proc. R. Soc. Tasm., 117: 41-51. https://doi.org/10.26749/rstpp.117.41 ISSN 0080-4703.

Department of Botany, University of Tasmania, Hobart, Tasmania, Australia.

The development of lichenology in Tasmania is outlined from the first lichen collections in the late eighteenth century. Special reference is made to the contributions of J.J. Labillardière, Robert Brown, Joseph Hooker, Ferdinand von Mueller and F.R.M. Wilson.

\section{INTRODUCTION}

The term 'lichen' literally means eruption or wart. It was first coined in the botanical sense by Theophrastus, a pupil of Aristotle and Plato, who lived in Ancient Greece in 371-284 B.C. (Richardson 1975). Theophrastus included a small number of lichens in his History of Plants, one of the earliest botanical treatises known, and a work which earned him the title of 'Father of Botany'. Subsequent references to lichens occur in many European herbals produced during the next 2000 years, a period in which the study of plants centred around their medicinal properties, both real and imagined.

With the development of systematic botany in the late 17 th century, lichens were given only scant attention. For example, Linnaeus was no lichenologist despite his achievements in botany as a whole. In fact, he rather despised lichens, calling them 'the poor trash of vegetation' (rustici pauperrimi) (Smith 1921). He grudgingly created a solitary genus, Lichen, comprising eighty species (Linnaeus 1753). The genus contained seven sections based on growth forms and was grouped with the algae.

Lichenology was established as a separate branch of Botany in 1803 when Erik Acharius, a country doctor from Sweden, published his Methodus Lichenum. He elevated the lichens to a separate Order consisting of twenty-eight genera. More importantly, however, he recognised characters that are still used today in lichen taxonomy and devised specialist terminology to describe them.

\section{CONTRIBUTIONS OF THE EARLY EXPLORERS}

The earliest published account of an Australian lichen relates to Baeomyces reteporus Labill. (now known as Cladia retipora (Labill.) Nyl.), collected in Tasmania by Jacques Julien de Labillardière (Labillardière 1807). Labillardière was the botanist and chief scientist on a French expedition commanded by Bruni D'Entrecasteaux in the ships "Recherche" and "Esperance". The French were in Australian waters for nearly four years, including two periods in southeast Tasmania (April 1792 and January 1793). In this time, valuable natural history collections were made, observations of the land and its inhabitants recorded and charts constructed. The expedition suffered an ignominious end, destroyed by disease, mutiny and imprisonment in the Dutch colonies in the Moluccas. However, Labillardière survived and eventually returned to France in 1796 . He proved an interesting and fluent writer, producing a general account of the voyage in 1800 , Relation du Voyage à la Recherche de la Pérouse. His greatest work, however, is his book on the botany of the voyage, Novae Hollandiae Plantarum Specimen, published in two parts in 1804 and 1807. The book is the first botanical work devoted to the flora of Australia and Tasmania and describes 265 species. Baeomyces reteporus is the only lichen recorded. Its description is in the style of Acharius but since the whole work is arranged according to the system of Linnaeus, Baeomyces, together with a liverwort, is classed with the Algae. The collecting locality is given as 'Capite Van Diemen' (= Cape Van Diemen), a general name under which Labillardière lumped all of his Tasmanian collections. (No Cape Van 
Diemen exists in Tasmania. Bass Strait was not discovered until 1797 and Labillardière's name plobably derives from the idea that Tasmania was a cape of mainland Australia.) The localities he would probably have visited range from Recherche Bay and D'Entrecasteaux Channel to Storm Bay and the Derwent River estuary as far as Glenorchy Rivulet.

Although Labillardière provides the first description of an Australian lichen, it is uncertain whether or not his is the first Australian species to be collected. Baeomyces retepoms is listed in Systema Vegetabilium (Sprengel 1827) where it is accompanied by a lichen from King Island (Sticta delisea Fée) with no acknowledgement of a collector. It also appears in Synopsis Methodica Lichenum (Acharius 1814), under the new name of Cenomyee retipora (Labi11.) Ach., together with another lichen from Australia, Colzema tremeZzoides (= Leptogizm tremeZzoides (L.fil.) Gray). Acknowledgement for this species is given to Carl Peter Thumberg, a Swedish naturalist who never visited Australia. Although its true collector is unknown, the specimen may have been obtained from Johann Reinhold Forster with whom Thunberg is known to have occasionally exchanged specimens (Hoare 1976). Forster was the naturalist with Captain James Cook's second voyage (17721775 ) in the "Resolution" and the "Adventure". Although the "Resolution" (with Forster on board) did not visit Australia, the "Adventure", commanded by Tobias Furneaux, stopped briefly in Tasmania (at Louisa Bay and Adventure Bay) and very cursory collections of natural history specimens were made (Nelson 1981). When the two vessels were eventually reunited in New Zealand, Furneaux generously gave Forster some zoological specimens he had collected in Tasmania. Nelson (20c. cit.) has suggested that Furneaux may have also given some botanical specimens to Forster. If this were true, then Thunberg's 1ichen may well have been received from Furneaux via Forster and would predate Labillardière's collection by twenty years.

The voyage of D'Entrecasteaux was followed by another French expedition, that of Nicolas Baudin in the ships "Geographe" and "Naturaliste". The expedition was in Australian waters between 1800 and 1804 and, in addition to landfalis on the mainland, explored Tasmania's east coast, D'Entrecasteaux Channel and King Island. Although extensive botanical collections were made by Leschenault de la Tour and his assistant, Guichenot, no comprehensive account of the botany of the voyage was attempted and the existence of any lichen collections is therefore not known.

In 1801, the British Government commissioned the "Investigator", under the command of Natthew Flinders, to undertake a survey of the south coast of Australia. Accompanying the voyage was Robert Brown, a young and energetic botanist from Scotland. Despite a brief anchorage off King Island in Bass Strait, no landfalls were made in Tasmania. However, Brown was later to spend nine months in the state, arriving in 1803 with Lieutenant Bowen and the first settlers on the "Lady Nelson". The settlement at Risdon Cove was established and most of his time was spent there. He also participated in the founding of the settlements at Port Dalrymple (Tamar River) and Sullivans Cove (Hobart). Overall, Brown was unimpressed by the flora of Tasmania:

"The whole number of plants observed in this port did not much exceed 300, of which about 40 were new to me and, I believe, non-descript."

(from Maiden 1909)

Nevertheless, over half of Brown's lichens were collected in Tasmania and, in view of his comments above, this may have resulted from his lack of enthusiasm for the higher plants of the state.

In 1810, Brown published his Prodromus Florae Novae HoZlandiae et Insulae Van Diemen, a botanical masterpiece that eclipsed Labillardière's as the flora of the region. It dealt with 4200 plants (3900 from his personal collection) but contained no cryptogams. In the appendix to Flinders' A Voyage to Terra Australis (1814) Brown notes:

"... [the Cryptogams] were not, it must be admitted, equally attended to."

Also in the appendix, he included a list of fifty-eight species of lichen shared by Australia and Europe with the comment that this constitutes about two-thirds of the 
G. Kantvilas

diversity. No localities are cited. Although it is said that he planned to publish a more detailed catalogue of lichens (Crombic 1880), this did not eventuate. He died in 1858 and his collection remained in obscurity for twenty years in the British Museum. In 1880, the Reverend James Crombie, a leading British lichenologist, published a catalogue of lichens from Brown's herbarium. It contained 75 species, including 12 descriptions of new lichens, three by Crombie, seven by the French lichenologist, William Nylander, and two by Brown himself that had been found in his notes. Forty-two of these lichens are from Tasmania, the localities being "Derwent River", "Table Mt. (= Mount Wellington) and its foothills" and "Risdon Cove". The localities, however, should be treated with extreme caution. Two of the new species from Mount Wellington, Tasmania, Parmelia australiensis Crombie and Chondropsis semiviridis F. Muell. ex Nyl., have never since been reported from Tasmania. Both are found along the arid coast of the Great Australian Bight so it seems quite likely that either Brown or Crombie muddled their labels (see Paulson 1930 and Filson 1976).

\section{THE EARLY COLONIAL PERIOD}

\section{Contributions of the English}

With the establishment and growth of the Australian colonies, the main thrust of botanical exploration shifted from the sea-faring botanist confined to the coast, to the resident with access to the inland. Sir Joseph Banks, who had previously ensured that botanists accompanied the British voyages of discovery, began to send collectors to the colonies or to recruit the settlers themselves. Banks' first envoy was George Caley who visited Tasmania briefly in 1805 but did not collect any lichens. His successor was Alan Cunningham who achieved fame not only as a botanist but also as an explorer. He visited Tasmania in 1818 aboard the "Mermaid" whilst on a survey of the coasts of Australia with Philip Parker King. Macquarie Harbour, Hobart and Mount Wellington were visited. The only Tasmanian lichen known in his collection is Cladonia rangifera (L.) Web. (mistakenly cited as C. rangiferina Hoffm. in Babington \& Mitten 1860).

With the death of Banks in 1820, the task of corresponding with the Australian colonies fell to William Jackson Hooker. Hooker tried to establish correspondence with someone in Tasmania but initially without success. At length, in 1827, he received his first favourable reply, from Thomas Scott, a merchant of Launceston. Scott was at best a very reluctant collector. His correspondence was sporadic and his gatherings scanty, usually of seeds. He has earned his place in this discussion not for any contribution to lichenology but because he was the first of a long line of Tasmanian collectors. His most important letter to Hooker came in 1830, when he introduced Robert William Lawrence as a prospective collector for Kew:

"... he is a young man, very anxious to learn and I have no doubt but you will find him a very valuable correspondent."

(from Burns c̊ Skemp 1961)

Son of William Effingham Lawrence, a wealthy landowner of Launceston, Robert Lawrence was a man of leisure. Unlike Scott, he had an avid interest in science, devoting much of his spare time to botany. In his first meek letter to Hooker he wrote:

"My knowledge of this science [i.e. Botany] is certainly very slight indeed, I am a mere learner ... but I hope that in time, by application, I shall become as much of a Botanist as to enable me to be useful to you if you will accept my services such as they may be."

(Burns \& Skemp 1961)

To learn in a remote place like Tasmania must have been an arduous task. He had no books, nor paper, nor colleagues with whom to discuss his work, and his only advisor was thousands of miles away. Nevertheless, each shipment of specimens, and these included many lichens, was rewarcled with gifts of books and encouragement from Hooker. 
Lawrence was not alone in his pursuit of botany for long. Through the social life of Launceston, he met a young man of his own age and outlook, Ronald Campbell Gunn. Born in South Africa, Gunn had been educated towards a military career in Scotland. He migrated to Tasmania on the advice of his brother and obtained employment as a superintendent of convicts in Hobart. He was ambitious and hardworking, and in the short space of three years he was promoted to a Police Magistrate in Launceston, in control of all the convicts in northern Tasmania. Gunn and Lawrence became great friends and soon Lawrence, echoing the words of scott a few years earlier, was writing to Hooker:

"Give me leave to introduce to you my friend Mr. Gunn, a gentleman who has lately acquired a passionate taste for the science of Botany and who has become an enthusiastic collector."

(Burns \& Skemp 1961)

With Hooker's guidance, they devoted their energies to science and the pursuit of knowledge. Unfortunately, their close fricndship was cut short in 1833 by the tragic death of Lawrence on his twenty-sixth birthday. Gunn was shattered, but not even the death of his friend and colleague could deter him from his new interest. He wrote to Hooker:

"His loss to you will be most severe, as he was years ahead of me in experience, both of Botany and the localities of the plants of Van Diemen's Land - I can only, however, promise to do all I can and trust that time will improve me."

(Burns \& Skemp 1961)

The work of responsible correspondents such as Lawrence and Gunn proved invaluable to William Hooker (and others) in England whose studies on the Australian flora relied completely on the receipt of adequate specimens from the colonies. Hooker's links with Tasmania were strengthened with the arrival in Hobart of his son, Joseph Dalton Hooker, in 1840. He accompanied an expedition comnanded by Sir James Clarke Ross in the ships "Erebus" and "Terror". Although Joseph Hooker was employed as assistant surgeon aboard the "Erebus", he was an adept botanist, as was David Lyall, his counterpart on the "Terror". The aim of the voyage was to study terrestrial magnetism, but due to the enthusiasm and expertise of its members the greatest contributions proved to be in natural history. The ships arrived in Hobart on 16th August 1840 via the Cape of Good Hope and Kerguelen Island. The botanists rapidly made their acquaintance of Gunn and in the course of their three-month stay collected in the Derwent and Clyde Valleys, the Central Plateau and Port Arthur. After spending that summer in Antarctic waters, they returned to Hobart on 7th April 1841 for another three-month sojourn. This time collections were made from the Huon valley and the Richmond area. Inevitably, Joseph Hooker and Ronald Gunn became close friends and later Hooker wrote:

"... [I] am indebted to him for nearly all I know of the vegetation of the districts I visited. I can recall no happier weeks of my various wanderings over the globe than those spent with Mr Gunn, collecting in the Tasmanian mountains and forests, or studying our plants in his library."

(Hooker 1860)

Three years in al1, between 1839 and 1842 , were spent in southern waters, visiting Tasmania, New Zealand, Antarctica, the subantarctic islands and southernmost South America. An enormous collection, consisting of marine animals as well as plants, had been amassed in that time. Largely at the insistence of his father, Joseph Hooker embarked on the ambitious project of writing an account of the botany of the regions he visited.

Although he was one of the more promising English botanists of the time, Joseph Hooker was not an accomplished lichenologist. For the study of this group he secured the assistance of Thomas Taylor, Professor of Botany at Cork and an expert on lichens, mosses and liverworts. In 1844, they published a catalogue of 151 lichens collected on the voyage. Fifty-four of these were new species, eleven from Tasmania (Hooker \& Taylor 1844). In the same year, the first part of J.D. Hooker's Botany of the Antaretic Voyage (i.e. Flora 


\section{G. Kantvilas}

Antaretica, Vol. I) appeared, containing a section on lichens by Taylor and Hooker. Taylor published additional contributions alone, including the description of two mainland species from Alan Cunningham's lichen collection (Taylor 1844). In the description of one of these species, Taylor acknowledges a specimen from Tasmania collected by Dr Balfour. Another publication followed in 1847 describing three new Tasmanian species. The source of these in "Mr. Borrer's herbarium" (Taylor 1847). However, William Borrer, a renowned British botanist and lichenologist, never visited Tasmania, so the true collector of these lichens is unknown, al hough wetmore (1963) infers that they were collected by Lawrence. Taylor died in 1848 and subsequent studies on the lichens from the voyage were undertaken by the Reverend Churchill Babington who, in addition to his botanical pursuits, was also Professor of Archaeology at Cambridge.

1860 saw the publication of Flora Tasmaniae, part 3 of J.D. Hooker's Botany of the Antaretic Voyage and a landmark in the history of Tasmanian botany. The work was dedicated to Ronald Campbell Gunn and William Archer, a friend of Hooker, "for their indefatigable exertions" (Hooker 1860). The colonial government of Tasmania contributed 350 towards publication costs, supplementing $\$ 1000$ provided by the British Government Treasury. A further 100 was donated by Archer. The work, dealing with angiosperms, gymnosperms, pteridophytes, bryophytes, algae, lichens and fungi, was the first attempt to document the total flora of Tasmania, a feat which has never since been repeated despite subsequent revisions of selected plant groups.

The lichen section of Flora Tasmaniae was written by Babington, with assistance from William Mitten with the crustose species. Mitten was a young bryologist who had risen to prominence with the death of Taylor. All in all, 93 lichens were enumerated, two of which were described as new (Sticta cetrarioides Bab. [= Heterodea muelieri (Hampe) Nyl.] and Baeomyces heteromorphus $\mathrm{Ny}$ 1.). Specimens from a variety of sources were acknowledged. These included the collections of Lawrence and Gunn, as well as the vast herbarium amassed by Hooker and Lyall on the Antarctic voyage. In addition, many specimens were obtained from Archer who was an enthusiastic plant collector. Born in Launceston and educated in England, Archer lived on his estate, "Cheshunt", near Deloraine. He practised as an architect, designing the old Hutchins School in Hobart and other buildings. He was also a. painter and his works include the orchid plates for the Flora Tasmaniae.

Further specimens for the Flora had been provided by Ferdinand von Mue11er. Mueller had emigrated from Germany in 1847 and had settled in Adelaide where he worked as a pharmacist. His chief interest, however, was botany and he spent much of his spare time collecting and exploring. He established correspondence with William Hooker at Kew as well as with numerous other botanists, both abroad and in the Australian colonies. One of his first Tasmanian contacts was Charles Stuart whom he met in Adelaide in 1847. Stuart had collected for Gunn whilst working as a nurseryman in Tasmania. Evidently, however, the two had fallen out. In a letter to Mueller he wrote:

"Respecting the specimens left with Mr. Gunn, he has in a most unhandsome manner made away with them, and then made a paltry excuse, saying he thought I should not need them ... but after the number of specimens I have given him, and information he has got from me, I should not have thought him so bad, but the fact is he is jealous of any person's knowledge of plants lest it should discover his defects."

(Daley 1935)

Mueller befriended Stuart who, on returning to Tasmania, began to send plant specimens to him. Mueller also obtained Tasmanian plants from Augustus 01dfield, a botanist and explorer who collected in Western Australia and New South Wales as well as in Tasmania. The collections of Stuart and oldfield contained many lichens, some of which were placed at the disposal of Babington and Mitten for the Flora. Additional small contributions of specimens were obtained from the herbaria of Alan Cunningham, from Samual Mossman, a trave1ler who collected and sold botanical specimens and from the European lichenologist, Elias Fries. The latter never collected in Australia though he did have access to Australian collections (Wilson 1890). The source of his Tasmanian lichen is unknown. 


\section{Contributions of the French}

Although the Antarctic voyage of the "Erebus" and "Terror" ranks supreme in terms of botanical exploration in the southern zone, it was by no means a unique venture. A similar expedition was undertaken almost simultaneously by the French under the command of Dumont D'Urville. Although the achievements of this voyage are less weil known than those of the English, they are by no means insignificant. D'Urville was no stranger to Australian waters. He had visited Sydney in 1824 as a botanist aboard the "Coquille" commanded by Duperrey. In 1827, he visited Hobart in command of his own vesse1, the "Astrolabe". Although the botanical results of the expedition, published by Achille Richard and A. Lesson, deal largely with New Zealand, some Tasmanian lichens are also included (Lesson $g$ Richard 1832). This expedition was followed by a voyage to Antarctica in the "Astrolabe" and "Zélée", lasting from 1837 to 1840 . The voyage parallels that of Hooker, particularly in its study of terrestrial magnetism. Botanical collections were undertaken by Hombron, the surgeon, Jacquinot, the second-in-command and D'Urville himself. After a tortuous voyage through the Indian Ocean, the expedition limped into Hobart in December 1839. Dysentry and fever had ravaged their numbers and the time in port was spent in burying the dead and recuperating. From Hobart they sailed to Antarctica, discovering and claiming Adélie Land for France. The expedition returned to Tasmania in February 1840. Although D'Urville's time in Tasmania was short, he was well received and spent some time travelling, visiting Launceston and the midlands and climbing Mt Wellington. The Hobart Town Courier carried an account of his travels and an expression of his thanks to the people of Tasmania (see Triebel \& Batt 1957).

The botanical results of the expedition were published by Hombron \& Jacquinot in 1845 . In many respects the work overlapped with Joseph Hooker's Botany of the Antarctic Voyage. However, Hooker himself seemed unimpressed with the French work:

"They have published very few of my best plants, not my best at all, I am happy to say - their figures are very poor indeed and the depictions miserable."

(Hooker to Gunn 1844, from Moya1 1976)

The cryptoganic plants. were studied by the French lichenologist, Camille Montagne. His account of the lichens (Montagne 1845) lists species from the Pacific, the Straits of Magellan and New Zealand, as well as two species from Tasmania (Usnea flomida Hoffm. and CZadonia fureata var. pungens Floerke) collected at Hobart by Hombron. Montagne's work also contains one of the earliest accounts of the similarities in the 1 ichen floras of the northern and southern circumpolar regions.

\section{THE LATE NINETEENTH CENTURY}

By the middle of the nineteenth century a core of enthusiastic scientists had organised themselves in Tasmania. Personal visits by men of the calibre of Joseph Hooker had instilled encouragement and expertise in local botanists who in turn shared their knowledge with colleagues. Other visitors included Professor William Harvey from Dublin. A renowned phycologist, Harvey arrived in Tasmania in 1855 and rapidly established a network of algae collectors. However, his activities were apparently not restricted to the algae for a lichen from his Tasmanian collection, gathered jointly with Mr W.H. Ince, is mentioned in Chee1 (1924).

Ferdinand von Mueller, now based in Melbourne, had emerged as one of Australia's most accomplished botanists and had established a large network of collectors. In Tasmania, Charles Stuart remained his most active lichen collector and many of Stuart's lichens were forwarded to Dr E. Hampe in Germany. Hampe published a catalogue containing thirty-six Tasmanian lichens (Hampe 1852) including two new species, Lecidea stuartii Hampe and Biatora byssacea Hampe. Meller received other Tasmanian 1 ichens from collectors such as T.A. and B. Gulliver (who collected mainly on Mt Wellington), from Skelton Emmett (Circular Head), from Ambrose Neale (King Island) and from Dr George Fordyce Story, surgeon at Water10o Point Military Station near Swansea. These collections were sent to Anton von Krempelhuber in Munich (Krempelhuber 1881). Krempelhuber was no stranger to Australasian 
G. Kantvilas

lichens, having studied the collections of Karl von Hügel who had toured the world between 1831 and 1837. Most of Hügel's time in Australia in 1833 was spent at the Swan River Colony in Western Australia, although Krempelhuber (1868) attributes a few Tasmanian collections to him. Through his experience with Australian material, Krempelhuber was able to assist Mueller in compiling a list of lichens for his Fragmenta Phytographiae Australiae (1858-81) (Krempe1huber 1880).

Meanwhile in Geneva, much of the nomenclature of Australasian lichens was being revised by Dr Jean Muller in a series of publications dating from about 1878. This work included Tasmanian lichens from many earlier collections (Miller 1882a, 1882b, 1883, 1889) as well as a revision of Krempelhuber's work (Müller 1887). Müller also corresponded with Ferdinand von Mueller from whom he received lichen material including occasional specimens from Tasmania which Mueller had collected himself. Wetmore (1963) erroneously lists Amalie Dietrich and Franz Sieber as collectors of Tasmanian lichens published by Müller and Krempelhuber. Neither of these two collectors ever visited Tasmania. Sieber's specimen from "Mt. Wellington" is not from the Tasmanian peak of that name.

Additional studies on Tasmania's lichen flora were undertaken by Dr James Stirton, lecturer in gynaecology and Professor of Midwifery at Glasgow, Scotland. He devoted himself to the study of mosses and lichens, paying particular attention to the flora of Scotland. Later he received material from all over the world, including Tasmania, New Zealand, Australia, Canada, South America and South Africa (Trail 1917). The majority of his Tasmanian lichens were collected by Hugh Paton of Glasgow who toured Australia some time prior to 1880. Other Tasmanian specimens were obtained from Walter Campbel1, an inspector of agriculture in New South wales and part-time collector for Ferdinand von Mueller, from Mirs Heywood McEwen and from E. Spong of King lsland. All in all, Stirton described eight new species from Tasmania (Stirton 1876, 1882, 1898, 1900).

Up to this point, the history of Tasmanian lichenology has been a saga of the sporadic export of Tasmanian specimens for study by overseas experts. In fact, in the years following the publication of Hooker's Flora Tasmaniae, hailed as "the foundation of the whole cryptogamic botany of Australia" (Mueller 1881), there had been a gradual waning of interest in lichenology in Tasmania. In 1881, Ferdinand von Mueller appealed for someone to collect and study Tasmanian cryptogamic plants:

"It may be predicted with confidence that the number of mosses, 1ichens and algae of Tasmania will be still considerably augmented by assiduous and perservering searches."

(Mueller 1881)

In spite of Mueller's plea, local interest and expertise with Tasmanian cryptogams, especially lichens, was slow to develop. However, in 1884, the Royal Society of Tasmania gained three new members, all of whom were to make a significant contribution to bryology and/or lichenology. Nevertheless, none was to actually publish any lichenological works relevant to Tasmania. They were Richard Austin Bastow, William Anderson Weymouth and Leonard Rodway.

Richard Bastow arrived in Tasmania in 1884 from Manchester where he had been a sanitary surveyor. He began to study lichens and bryophytes, collecting over a wide area throughout Tasmania. He was a qualified architect and soon put these skills to use in illustrating his publications with excellent line drawings. Assisted by his friend, Mr C.J. Atkins, he often displayed labelled exhibits at meetings of the Royal Society. Unfortunately, his published works did not extend to Tasmanian lichens and although he was a true pioneer in developing a local lichenological following in Tasmania, he is best remembered today for his accounts of the mosses and liverworts (the first since those of Hooker in Flora Tasmaniae). In 1888, he moved to Melbourne where his attention turned to the Victorian flora.

In contrast to Bastow, Weymouth was a second generation Tasmanian 1 iving in Hobart. He was a prodigious collector of bryophytes and lichens, a hobby he adopted in 1887. Occasionally accompanied by his friend, the Reverend John Bufton, his collecting took him 
as far afield as Mt Bischoff and Mt Lyell on the west coast, Circular Head, Tasman Peninsula and Mt Arthur near Launceston. He corresponded with and sent specinens to numerous overseas experts and a catalogue of sixty-three lichens collected by him was published in Italy by Jatta. Ten new species, including ochrolechia weymouthii Jatta, and three new varieties were described (Jatta 1910). Like Bastow, Weymouth's greatest contribution to Tasmanian botany was in the field of bryology. Although he was working towards a bryophyte flora of Tasmania, the final work was undertaken by Leonard Rodway in 1912 . Rodway became the greatest Tasmanian botanist of the time and author of more than fifty works, including the Flora of Tasmania in 1903. Although he made occasional collections of lichens (Cheel 1912, 1914) they proved to be one of the few plant groups he did not study in detail.

Despite the large collection of lichens amassed by Bastow and Weymouth, it was left to mainland lichenologists to make the greatest contributions to Tasmanian lichenology. Prior to his move to Melbourne, Bastow had hoped to describe the lichen flora of the island but this work had been abandoned. Instead he passed the project and his collection to his good friend, the Reverend Francis Robert Muter Wilson, a Presbyterian minister stationed at Kew in Melbourne. Wilson was Australia's most productive lichenologist. He maintained active correspondence with European specialists such as Jean Müller but he also published a great deal of his own work in a series of about twenty papers (Filson 1976) between 1887 and his death in 1903. In the early $1890^{\prime} \mathrm{s}$ he visited Tasmania, collecting at Launceston and Mt Arthur, St Marys Pass, Ulverstone, Hobart and Mt Wellington and the Huon River. He also made the acquaintance of local Tasmanian naturalists, notably Weymouth in Hobart and Augustus Simson, the founder and secretary of the Northern Tasmanian Natural Science Association in Launceston. Simson had arrived in Tasmania in 1873 and moved to Launceston in 1879, where he ran a stockbroking business in partnership with his brother. His lichen collections were mostly from Mt Wellington, the Blue Tier and Georges Bay. Wilson was given access to both Simson and Weymouth's private herbaria. He also obtained specimens from Miss Lilley (of Launceston) and a person called Coates, as well as some lichens from the Gordon River collected by Morton Allport. Allport, who died in 1878, was a lawyer, naturalist and bushwalker and was generally regarded as one of the most successful locally educated figures of the time.

In 1893, Wilson published a list of 151 Tasmanian lichens based on his own collections and those of the Tasmanian naturalists listed above, as well as on the lichen section in Flora Tasmaniae (Wilson 1893). In addition, he acknowledged a single gathering by Jules P. Verreaux (previously examined in France by Nylander in 1860) who had visited Tasmania between 1842 and 1847 as a collector for the Museum of Natural History in Paris. Wilson updated much of the earlier work on Tasmanian lichens and included brief descriptions of all the species. This paper remains the most comprehensive account of the Tasmanian lichen flora to this day.

In addition to Wilson, another prominent lichenologist, John Shirley, had emerged in Australia. Shirley had emigrated to Queensland in 1878 , after receiving his B.Sc. in London as a student of the famous Thomas Huxley. In Queensland he worked first as a teacher and then as a school inspector, a job which enabled him to travel widely and nurture his broad interests in biology and geology. However, it was in lichenology that he particularly excelled and his studies led to the publication of the Lichen Flora of Queenstand in 1888-89. He visited Tasmania in 1892 for a meeting of the Australasian Association for the Advancement of Science, during which time he collected at Mt wellington. He also met Weymouth who had presented a paper on the bryophytes of Tasmania to the meeting and who gave him a selection of lichen specimens from his herbarium. Shirley's first contribution to Tasmanian lichenology was a catalogue to 158 species based on virtually all of the early literature (Shirley 1893). The following year he produced an additional list of fifty-five lichens based on his own and Weymouth's collections (Shirley 1894). Seven new species were described, including Patellaria weymouthii Shirley. In 1912, Shirley gained a D.Sc. from the University of Sydney for a thesis entitled "The Thallus of the Genus Parmelia". It is of some interest that this celebrated work was subsequently published in Tasmania by the Royal Society (Shirley 1918). 


\section{G. Kantvilas}

\section{THE TWENTIETH CENTURY}

The dawn of the twentieth century saw the death of Wilson and the subsequent decline of lichenology both in Tasmania and Australia. Australian lichenology as a whole sustained a great tragedy with the loss of a crate of Wilson's type specimens en route to italy in 1907 (see Filson 1976). In Tasmania, the void left by Bastow and Weymouth remained unfilled and al though occasional isolated collections were still made, there was no systematic, large-scale lichen collecting undertaken. A small number of specimens found their way into overseas publications. Gustav Weindorfer, an Austrian-born naturalist living at Waldheim, Cradle Mountain, sent lichens to Zahlbruckner who described the new species Menegazaia weindorferi Zahlbr. from Mt Roland in his honour (Zahlbruckner 1906). The British botanist, Lilian Suzette Gibbs collected Tasmanian lichens during her visit in 1914 (Gibbs 1920, Wetmore 1963). Still other collections, however, were left unstudied, a fate destined for F.E. Burbury's collection from northeast Tasmania made between 1880 and 1920 , and now lodged in the Tasmanian Herbarium.

A small nucleus of lichenological activity in Australia centred around Edwin Cheel at the National Herbarium in Sydney. After humble beginnings, first as a farm labourer in Queensland and later as a gardener at Centennial Park in Sydney, Cheel became an expert in cryptogamic plants, largely through the encouragement of Joseph Henry Maiden. In 1901, he was placed in charge of the lichens at the National Herbarium and was promoted to Curator in 1924. He received many Tasmanian lichens and numerous minor collections are cited by him in his largely bibliographic publications (see Cheel 1912, 1914, 1924). His collectors included the algologist A.H.S. Lucas (collections from Mt Wellington and the Hartz Mts), J.H. Maiden and the writer and artist, Caroline Louisa Waring Atkinson (collections from Waratah).

In 1963, C1ifford Wetmore in the U.S.A. published a catalogue of Tasmanian lichens, drawing together into a single paper all the literature concerning the lichen flora of the island. He also included a directory of collectors and the location of their collections. Although no taxonomic revision was attempted, Wetmore (1963) expressed the hope that this would be prompted by his paper. No such work, however, has yet eventuated.

In May 1974, at a meeting held at the National Herbarium in Melbourne, the Australasian Association for Lichenology was formed in response to a renewed interest in lichens and with the intention of charting the future course of Australian lichenology. One of the founding members was a Tasmanian, Geoffrey Charles Bratt. A graduate of the University of Tasmania, Bratt gained his Doctorate in Chemistry at the University of London. His interest in lichens began in 1958 whilst on a glaciological expedition to Patagonia. He returned to Tasmania in 1959 to work as a research chemist at the Electrolytic Zinc Company. A keen bushwalker and mountaineer, he turned these skills towards lichen collecting and amassed what is undoubtedly the most extensive collection of Tasmanian lichens. Many specimens were sent overseas to numerous experts, one of whom, Theodore Esslinger, named the New Zealand endemic species Parmelia brattii in his honour. Bratt wrote a number of short papers on the Tasmanian lichen flora but his work ended abruptly in 1977 with his untimely death. His collection, amounting to 15000 specimens, is lodged in the Tasmanian Herbarium.

Despite the loss of this great collector, Tasmanian 1 ichenology has not languished. Recent visits by overseas specialists have inspired continued interest in Tasmanian lichens, ensuring that lichenology will no longer be the neglected aspect of natural history in Tasmania.

\section{ACKNOWLEDGEMENTS}

I would like to acknowledge with thanks the many helpful comments and suggestions made by Dr J. Jarman in the preparation of this paper. I would also like to thank Dr A.E. Orchard (Tasmanian Herbarium), Mr P. Minchin and Mr A. Mills (University of Tasmania) for their comments on the completed manuscript. Mr H. Mayrhofer (University of Graz, Austria) and Mr P. James (British Museum) assisted by providing copies of publications unavailable in Tasmania. 


\section{REFERENCES}

Acharius, E., 1814: SYNOPSIS METHODICA LICHENUM. Lund.

Babington, C. and Mitten, W., 1860: Lichenes. In Hooker, J.D.: FLORA TASMANIAE. Lovel. Reeve, London. Vol. II: $343-354$.

Brown, R., 1814: General remarks, geographical and systematical, on the botany of Terra Australis. In Flinders, M.: A VOYAGE TO TERRA AUSTRALIS. London.

Burns, T.E. and Skemp, J.R., 1961: Van Diemen's Land Correspondents. Rec. Queen Vict, Mus., 14: 1-142.

Cheel, E., 1912: Australian and south sea Island stictaceae. Rep. Australas. Assoc. Adv. Sei., 13: 254-270.

, 1914: Australasian and South sea Island Stictaceae. Rep. Austrazas. Assoc. Adv. Sei., 14: 311-320. , 1924: Notes on a coral lichen. Australian Wat., 5: 183-186.

Cronbie, J.M., 1880: Enumeration of Australian lichens in Herb. Robert Brown (Brit. Mus.). with descriptions of new Species. Jour. Linn. Soc. Lond. (Botany), 17: 390-401.

Daley, C., 1935: Charles stuart, an early Australian botanist. Vict. Nat., 52: 106-110, $132-137,154-157$.

Filson, R.B., 1976: Australian Lichenology: a brief history. MueZ2eria, 3: 183-190.

Gibbs, L.S., 1920: Notes on the phytogeography and flora of the mountain summit plateaux of Tasmaria. Jour. Ecol., 8: 89-117.

Hampe, E., 1852: Plantae Muellerianae - Lichenes. Linnaea, 25: 709-712.

Hoare, M.E., 1976: THE TACTIESS PHILOSOPHER. Hawthorn Press, Melbourne.

Hooker, J.D., 1860: FLORA TASMANIAE. Lovell-Reeve, London. and Taylor, T., 1844: Lichenes Antarctici; being characters and brief descriptions of the new Lichens discovered in the southern circumpolar regions, Van Diemen's Land and New Zealand, during the Voyage of H.M. Discovery Ships Erebus and Terror. London Jour. Bot., 3: 634-658.

Jatta, A., 1910: Lichenes lecti in Tasmania a W. Weymouth. Bulz. Soc. Bot. Italiana, (1910): 253-260.

Krempelhuber, A. von, 1868: Exotische Flechten aus dem Herbar des k. k. botanischen Hofkabinetes in Wien. Verhandz. zool.-bot. Ges. Wien, 18: 303-330.

, 1880: Lichenes Australiani e Baronis de Mueller collectionibus. In Mueller, F. von: FRAGMENTA PHYTOGRAPHIAE AUSTRALIAE. Govt Printer, Melbourne. Vol. XI (suppl. 5): $70-73$.

, 1881: Ein neuer Beitrag zur Flechten - Flora Australiens. Verhandz. zoot.-bot. Ges. Wien, 30: 329-342.

Labillardière, J.J., 1804-1807: NOVAF HOLLANDIAE PLANTARUM SPECIMEN. Paris. Vol. II: $109-110$.

Lesson, A. and Richard, A., 1832-1834: Botanique. In Dumont D'Urville: VOYAGE DE DÉCOURVETES DE L'ASTROLABE, EXÉCUTÉ PAR ORDRE DU ROI, PENDANT LES ANNÉES 1826-1829 SOUS LE COMMANDEMENT DE M. J. DUMONT D'URVILIE. Paris. (not seen)

Linnaeus, C., 1753: SPECIES PLANTARUM. 1959 facsimile edition, Adland and Sons, London. Maiden, J.H., 1909: SIR JOSEPH BANKS, FATHER OF AUSTRALIA. Govt Printer, Sydney.

Montagne, C., 1845: Plantes cellulaires. In Dumont D'Urville (1842-1845): VOYAGE AU PÔLE SUD ET DANS L'OCEANIE SUR LES CORVETTES L'ASTROLABE ET LA ZÉLËE PENDANT LES ANNÉES 1837-1840, SOUS LES COMMANDEMENT DE M. J. DUMONT D'URVILLE. Paris. Botanique I: 169-201.

Hoyal, A.M., 1976: SCIENTISTS IN NINETEENTH CENTURY AUSTRALIA: A DOCUMENTARY HISTORY. New Century Press, sydney.

Mueller, F. von, 1881: Suggestions for an elucidation of the plants of Tasmania. Pap. Proc. R. Soc. Tasm., (1881): 22-25.

Müller, J., 1882a: Lichenologische Beiträge XV. Flora, 65: 295, 299.

… 1882b: Lichenologische Beiträge XVI. F20ra, 65: 486.

, 1883: Lichenologische Beiträge XVII. Flora, 66: 22, 24, 75-76.

1887: Revisio lichenum australiensium Krempelhuberi. FZora, 70: 113-118.

1888: Lichenologische Beiträge xxx. Flora, 71: 546.

1889: Lichenologische Beiträge XXXII. FZora, 72: 507.

Nelson, C.E., 1981: The natural history observations and collections made during Furneaux's visit to Tasmania (Van Diemen's Land) in 1773 with special reference to botany. Pap. Proc. R. Soc. Tasm., 115: 77-84. 
G Kantvilas

Paulson, R., 1930: Pamelia alstratiensis Crombie - a rediscovered species. Jour. Bot., $(1930): 129-130$.

Richardson, D.H.S., 1975: THE VANISHING LICHENS. David and Charles, London.

Shirley, J., 1893: A list of the known lichens of Tasmania. Pap. Proc. R. Soc. Tasm., (1892): 179-191.

, 1894: Notes on Tasmanian lichens. Pap. Proc. R. Soc. Tasm., (1893): $214-219$. $53-6 \overline{8}$.

Smith, A. L., 1921: LICHENS. Cambridge University Press, Cambridge.

Sprengel, K., 1827: CAROLI LINNAEI SYSTEMA VEGETABILIUM. Gotlingen. (not seen)

Stirton, J., 1876: Lichens, British and foreign. Trans. Glasgow Soc. Fiezd Natural., 4: 85-95.

- 1882: Notes on the genus Usnea, with descriptions of new species. Scottish Natural. (Perth), 6: 292-297.

- 1898: On new Australian and New Zealand lichens. Trans. Proc. N.2. Inst. (Botany), 30: 382-393.

, 1900: On new lichens from Australia and New Zealand. Trans. Proc. N.Z. Inst. (Botany), 32: 70-82.

Taylor, T., 1844: Descriptions of new mosses and lichens from the Australian colonies. Phytologist, 1: 1093-1096.

1847: New lichens, principally from the herbarium of W.J. Hooker. London Jour. Bot., 6: 148-197.

Trail, J.W.H., 1917: Obituary: James Stirton. Proc. Linn. Soc. London, (1916-1917): $71-75$.

Triebel, L.A. and Batt, J.C., 1957: FRENCH EXPLORATION OF AUSTRALIA WITH SPECIAL REFERENCE TO TASMANIA. Tasm. Govt Printer, Hobart.

Wetmore, C.M., 1963: Catalogue of the lichens of Tasmania. Rev. Bryol. et Lichenol., $32: 223-264$.

Wilson, F.R.M., 1890: Australian Lichenology. Rep. Australas. Assoc. Adv. Sei., (1890): $549-553$.

- 1893: Tasmanian Lichens. Pap. Proe. R. Soe. Tasm., (1892): 133-178.

Zahlbruckner, A., 1906: Neue Flechten III. Ann. Mycol., 4: 486-490. 